\title{
PRONUNCIATION DIFFICULTIES ENCOUNTERED BY EFL STUDENTS IN INDONESIA: SEBUAH STUDI KASUS PADA MAHASISWA KELAS INTEGRATED COURSE SEMESTER 1 FKIP BAHASA INGGRIS UNIVERSITAS KANJURUHAN MALANG
}

\author{
Agus Sholeh \& Uun Muhaji \\ Dosen Pendidikan Bahasa Inggris Universitas Kanjuruhan Malang \\ Email: uun.muhaji@gmail.com
}

\begin{abstract}
Abstrak
Dalam pengajaran Bahasa Inggris sebagai Bahasa asing di Indonesia, ada cukup banyak masalah yang dihadapi oleh para siswa yang menjadi penghalang bagi pengembangan kemampuan berbahasa Inggris mereka. Salah satu masalah yang sulit namun sudah cukup familiar yaitu permasalahan pronunciation pada kemampuan berbicara (speaking). Penelitian ini bertujuan untuk secara khusus mengivestigasi dan menjelaskan kemampuan pronunciation serta masalah atau kesulitan terkait pronunciation yang dihadapi oleh mahasiswa Prodi Pendidikan Bahasa Inggris Universitas Kanjuruhan Malang yang mengambil mata kuliah Integrated Course pada semester satu. Penelitian ini juga bertujuan untuk menyediakan solusi yang dapat digunakan untuk membantu mengatasi masalah-masalah pronunciation para mahasiswa. Identifikasi dan solusi tersebut diharapkan dapat berguna bagi para dosen yang mengajar mata kuliah Bahasa Inggris. Dalam jangka panjang, diharapkan kemampuan pronunciation mahasiswa dapat meningkat sehingga kemampuan berbicara mereka juga meningkat.
\end{abstract}

Kata kunci: Pronunciation, study kasus, kesulitan, integrated course.

\section{Abstrack}

In the teaching of EFL in Indonesia there are many problems faced by students that hinder them from improving their English skills and abilities. One of the most familiar yet difficul one is pronunciation problem in speaking proficiency. This study aims to particularly investigate and provide the explanation of the pronunciation proficiency of and the pronunciation problem encountered by English Education Department students taking Integrated Course at the first semester in Kanjuruhan University of Malang. This study is also conducted to provide the possible solution in helping students with their pronunciation problems. The identification and solution provided are hoped to be useful for the lecturers teaching English at this department in helping their students deal with the pronunciation problems they faced. Thus, in the long run, it is hoped that students' pronunciation profiency will be improved and therefore their speaking skill is also improved.

Key words: Pronunciation, case study, difficulties, integrated course.

Pronunciation adalah salah satu bagian dari speaking skill yang akan secara langsung dan gamblang bisa diobservasi dan diketahui. Ketika seseorang berbicara dalam Bahasa Inggris maka orang yang mendengarkan akan secara langsung mengidentifikasi bagaimana pronunciation atau pengucapan dari orang tersebut. Ketika seseorang membuat kesalahan dalam pengucapan Bahasa Inggrisnya maka hal tersebut akan secara langsung dapat diketahui atau terdeteksi oleh orang yang mendengarkan. Berkaitan dengan hal tersebut, dalam pengajaran Bahasa Inggris, guru adalah seorang model penggunaan bahasa bagi anak didiknya. Oleh karena itu sudah seharusnya lah kemampuan yang dimiliki dapat dijadikan contoh penggunaan Bahasa Inggris yang baik dan benar bagi anak didiknya.

Karena terintegrasi pada mata kuliah yang lain, dosen tidak memiliki 
cukup banyak kesempatan untuk mempelajari kelemahan-kelemahan atau masalah-masalah pada pronunciation mahasiswa. Sementara itu, untuk mengoptimalkan perhatian pada pronunciation mahasiswa dosen harus memiliki cukup informasi dan data mengenai kesulitan apa saja yang dihadapi oleh mahasiswa. Oleh karena itu, perlu dilakukan sebuah studi untuk menemukan, mengidentifikasi dan menguji hal-hal yang berkaitan dengan kesulitan mahasiswa dalam pronunciation.

Secara spesifik, tujuan dari penelitian ini yaitu: 1) mengidentifikasi kemampuan mahasiswa FKIP Bahasa Inggris kelas Integrated Course semester satu Universitas Kanjuruhan Malang dalam hal pronunciation, 2) mengidentifikasi kesulitan yang dihadapi oleh mahasiswa FKIP Bahasa Inggris kelas Integrated Course semester satu Universitas Kanjuruhan Malang dalam mempelajari pronunciation, dan 3) merekomendasikan strategi dan hal-hal penting yang harus menjadi perhatian Dosen dalam mengajarkan pronunciation.

Pengajaran bahasa dapat diartikan sebagai aktifitas yang ditujukan untuk menghasilkan pembelajaran bahasa (Stern, 1991, pg.32). Oleh karena itu seorang guru atau dosen pengajar bahasa Inggris harus mampu menghasilkan sebuah proses pembelajaran bahasa bagi anak didiknya. Stern (1991, pg.32) juga menambahkan bahwa sebuah pengajaran bahasa yang baik akan memenuhi kebutuhan peserta didik dengan cara sebaik mungkin. Sebuah pengajaran bahasa yang baik perlu memperhatikan kondisi atau keadaan serta kebutuhan dari peserta didik berkaitan dengan proses pembelajaran bahasa tersebut. Sangat penting sekali bagi seorang guru atau pendidik untuk mengetahui serta mempelajari kebutuhan peserta didik dengan cara mengidentifikasi dan mengkaji kelemahan-kelemahan dan kesulitan yang dihadapi oleh peserta didik sehingga pendidik bisa mewujudkan proses pembelajaran yang sesuai dengan kebutuhan peserta didik.

Brown (2000, pg.7) menyatakan bahwa pengajaran tidak bisa dipisahkan dari pembelajaran. Mengajar berarti membimbing, dan memfasilitasi belajar atau proses pembelajaran, membuat peserta didik belajar dan menciptakan situasi untuk belajar. Pemahaman seorang guru mengenai bagaimana peserta didiknya belajar akan menentukan pandangannya mengenai pendidikan, gaya mengajar, pendekatan, metode dan juga strategi atau teknik dalam mengajar. Pemahaman yang terintegrasi mengenai peserta didik (kebutuhan, permasalahan serta kesulitan yang mereka hadapi) dan materi apa yang mereka pelajari akan memberikan jalan terbaik untuk menciptakan proses pembelajaran yang sukses dan sesuai dengan kebutuhan peserta didik (Brown, 2000, pg.8).

Oleh karena itu, dalam pengajaran bahasa, seorang guru atau dosen harus mengetahui skill apa saja yang menjadi kelemahan anak didiknya serta komponen apa saja yang menjadi kesulitan bagi anak didiknya. Dengan mengetahui kelemahan dan kesulitan tersebut diharapkan guru atau dosen dapat secara tepat menerapkan strategi pengajaran yang efektif serta membantu peserta didik untuk mengatasi kesulitankesulitan yang mereka hadapi.

\section{Speaking Skill}

Dalam pengajaran bahasa, terutama Bahasa Inggris, terdapat empat language skills yang menjadi perhatian guru yaitu: listening, speaking, reading, dan writing. Keempat language skills tersebut terbagi kedalam receptive skills (reading dan listening) serta productive skills (speaking dan writing). Dalam pengajaran bahasa, yang harus 
diperhatikan berkaitan dengan language skills tersebut adalah "what we do with the language" atau apa yang kita lakukan dengan bahasa tersebut (Scrivener, 2005, pg.29). Mengolah kemampuan atau skills dalam pengajaran atau pembelajaran bahasa Inggris adalah sangat penting. Pelajaran perlu direncanakan untuk memberikan kesempatan bagi peserta didik untuk mempraktikan atau mengolah serta meningkatkan kemampuan language skills mereka (Scrivener, 2005, pg.30). Lebih jauh Scrivener menyatakan bahwa mengolah kemampuan berbahasa atau skills ini bukanlah sesuatu yang ditambahkan pada saat akhir tetapi seuatu yang sangat penting yang harus menjadi inti dari pembelajaran Bahasa Inggris (2005, pg.30).

Sebagai sebuah makro skill, ada beberapa bagian dari speaking skill yang perlu diperhatikan yaitu: fluency (kelancaran berbicara), accuracy (ketepatan tata bahasa), vocabulary (kosakata), dan pronunciation (pengucapan). Setiap faktor tersebut memiliki peranan yang sangat penting dalam speaking skill, semakin bagus performance seseorang pada setiap faktor semakin bagus kemampuan berbicaranya dalam Bahasa Inggris. Fluency atau kelancaran adalah hal utama yang perlu diperhatikan oleh seseorang yang belajar Bahasa Inggris, sementara pronunciation dan vocabulary akan sangat membantu untuk mengembangkan fluency. Semakin bagus pronunciation dan semakin banyak vocabulary yang dikuasai maka akan semakin bagus fluency yang dimiliki. Selain itu, pronunciation adalah hal pertama yang akan sangat mudah untuk diidentifikasi dari kemampuan seseorang berbicara. Jika seseorang membuat kekeliruan dalam pronunciation maka akan diketahui pada saat itu juga.

Pengajaran pronunciation adalah bagian yang sangat esensial dalam pengajaran Bahasa Inggris. Pada satu sisi, pronunciation yang benar membantu seseorang untuk lebih percaya diri dalam berbicara dalam bahasa Inggris; pronunciation yang benar membuat orang lain (lawan bicara) lebih mudah untuk memahami maksud dari ucapan pembicara yang membantu kelancaran proses komunikasi dan pada akhirnya akan membantu pembicara untuk mengembangkan kemampuan berbicaranya. Pada sisi yang lain, pronunciation yang kurang bagus atau salah akan mengurangi atau menutupi kemampuan berbahasa Inggris yang baik dari seseorang; jika seseorang dapat berbicara dengan akurasi yang baik namun kata-kata yang diucapkan sulit untuk dipahami karena kesalahan pronunciation maka akan membuat komunikasi tidak berjalan dengan baik. Hal ini pada akhirnya akan mengurangi nilai kualifikasi dari seseorang.

Fraser (1999) menyatakan bahwa pronunciation adalah bagian yang sangat penting dalam pengajaran Bahasa Inggris. Namun lebih jauh Fraser menyatakan bahwa meskipun demikian, aspek pengajaran pronunciation ini masih menerima sedikit perhatian dari para pengajar. Alasan utamanya adalah ketidakpastian bagaimana cara terbaik untuk mengajarkan pronunciation (Fraser, 1999) dan juga karena biasanya tidak memiliki cukup waktu untuk memperhatikan hal tersebut dan sulit untuk mendeteksi kesulitan apa saja yang sebenarnya dihadapi oleh anak didiknya (Gilbert, 2008, pg.1). Oleh karena itu guru Bahasa Inggris harus mengetahui bagaimana cara mengajar pronunciation dan selain itu juga harus mengetahui apa saja kesulitan atau kelemahan anak didiknya dalam hal pronunciation. Mengajar pronunciation memberikan banyak tantangan bagi guru Bahasa Inggris (Gilbert, 2008, pg.1).

Metode Penelitian 
Metode yang digunakan pada penelitian ini adalah metode studi kasus. Metode ini melibatkan pengumpulan informasi secara sistematis mengenai seseorang tertentu, setting sosial, kejadian, atau sekelompok orang atau grup untuk memungkinkan peneliti dapat memahami secara efektif mengenai bagaimana sesuatu tersebut fungsi atau berjalan (Berg, 2001, pg.122). Secara khusus, penelitian studi kasus ini tidak melibatkan pengumpulan informasi secara sistematis mengenai seorang individu tetapi sebuah kelompok subyek yaitu mahasiswa Program Studi Pendidikan Bahasa Inggris kelas Integrated Course semester satu FKIP Universitas Kanjuruhan Malang. Adapun informasi yang akan dikumpulkan yaitu berupa kesulitan-kesulitan yang dihadapi mahasiswa dalam hal pronunciation ketika mereka belajar Bahasa Inggris. Data mengenai kesulitan tersebut didapat dari hasil analisis performance dalam tes pronunciation dan juga field notes. Informasi ini dikumpulkan dengan tujuan agar peneliti dapat menguji dan memahami mengenai apa saja kesulitan yang dihadapi oleh mahasiswa dan bagaimana kesulitan-kesulitan tersebut nantinya dapat diatasi oleh Dosen dan mahasiswa.

Subyek penelitian ini adalah mahasiswa yang menempuh mata kuliah Integrated Course pada semester satu Program Studi Pendidikan Bahasa Inggris Fakultas Keguruan dan Ilmu Pendidikan Universitas Kanjuruhan Malang. Sedangkan waktu pelaksanaannya yaitu selama semester Ganjil 2014/2015 pada saat proses perkuliahan Integrated Course. Data penelitian ini berupa data kualitatif. Data yang berupa pengetahuan dan performance mahasiswa dalam pengucapan atau pronunciation Bahasa Inggris dikumpulkan dengan cara melakukan pronunciation test dalam bentuk performance sesuai dengan jenis vocabulary yang mereka pelajari pada mata kuliah Integrated Course. Pengucapan atau pronunciation mahasiswa tersebut direkam untuk selanjutnya dievaluasi, diidentifikasi dan dianalisis. Evaluasi dilakukan untuk menilai kemampuan atau performance mahasiswa dalam hal pronunciation.

Untuk analisis data, selanjutnya peneliti mengidentifikasi jenis-jenis kesalahan yang dibuat oleh mahasiswa dalam pronunciation performance mereka untuk menemukan kesulitankesulitan apa saja yang mereka hadapi dalam pengucapan kata-kata dalam bahasa Inggris. Langkah terakhir yang dilakukan adalah menyimpulkan kesulitan-kesulitan yang dihadapi oleh mahasiswa dan hal apa saja yang harus menjadi perhatian Dosen untuk membantu mahasiswa menghadapi kesulitan-kesulitan tersebut. Analisis dilakukan untuk memformulasikan strategi dan treatment apa saja yang perlu dilakukan oleh dosen untuk membantu mahasiswa mengatasi kesulitan-kesulitan tersebut.

\section{Hasil Penelitian dan Pembahasan Kemampuan Pronunciation Mahasiswa FKIP Bahasa Inggris Kelas Integrated Course.}

Selama melaksanakan studi kasus ini peneliti menemukan bahwa sebagian besar mahasiswa semester 1 FKIP Bahasa Inggris yang menempuh mata kuliah Integrated Course memiliki kemampuan dasar yang cukup baik terkait skills reading, listening, dan writing. Namun, berkaitan dengan kemampuan speaking para mahasiswa sebagian besar memiliki permasalahan dengan akurasi dan pronunciation. Untuk mengetahui kemampuan pronunciation, peneliti melakukan test dalam bentuk reading aloud dan juga telling experience. Untuk dapat mengidentifikasi dan menganalisa pronunciation dari para mahasiswa 
peneliti merekam performance para mahasiswa tersebut. Kemampuan pronunciation para mahasiswa selanjutnya ditentukan dengan menggunakan panduan penilaian kemampuan pronunciation Pearson Test of English Academic (PTE Academic).

Berdasarkan identifikasi dan analisa data yang dilakukan oleh peneliti, dari 33 mahasiswa yang menjadi subjek penelitian ini, ditemukan bahwa sebanyak 2 orang mahasiswa kemampuannya masih berada pada level Non-English, 18 orang mahasiswa berada pada level Intrusive, 11 orang mahasiswa berada pada level intermediate, dan 2 orang berada pada level good.

Dapat disimpulkan bahwa terdapat lebih dari separuh jumlah mahasiswa dari keseluruhan subjek yang dianalisis yang kemampuan pronunciationnya masih berada pada level intrusive. Hal ini berarti kemampuan pronunciation para mahasiswa tersebut masih memiliki banyak sekali kekurangan. Dengan demikian hal ini menjadi tantangan yang cukup berat bagi para dosen pengampu mata kuliah Bahasa Inggris di Program Studi pendidikan Bahasa Inggris untuk membantu mahasiswa mengatasi kesulitan yang mereka hadapi terkait pronunciation Bahasa Inggris.

Kesulitan Mahasiswa FKIP Bahasa Inggris Kelas Integrated Course Dalam Mempelajari Pronunciation.

Peneliti mengidentifikasi kesulitankesulitan yang dihadapi mahasiswa dengan tiga cara, yaitu 1) melalui identifikasi hasil tes, 2) menggunakan Pronunciation Diagnostic Feedback (Gerhiser \& Wrenn, 2007), dan 3) melalui field note atau catatan lapangan yang dibuat oleh peneliti selama kegiatan penelitian. Hasilnya dapat diintegrasikan menjadi poin-poin utama kesulitan yang dihadapi mahasiswa dalam pronunciation Bahasa Inggris sebagai berikut:
1) Kesulitan dalam menghilangkan pengaruh Bahasa ibu yang masih kuat.

Sebagian besar mahasiswa masih mengalami kesulitan dalam menghilangkan pengaruh dari Bahasa ibu mereka. Pengaruh dari Bahasa ibu ini mengakibatkan mahasiswa kesulitan dalam pengucapan Bahasa Inggris yang lebih natural. Ketika berbicara Bahasa Inggris kata-kata yang diucapkan terdengar menjadi cenderung lebih berkarakter Bahasa ibu; misalnya lebih kental aksen Bahasa jawa, Bahasa flores, ataupun Bahasa ambon.

2) Kesulitan dalam pengucapan suara konsonan dan suara vokal yang tepat (Kesulitan dalam membiasakan diri dengan pengucapan suara fonetic dalam Bahasa Inggris).

Seringkali mahasiswa salah mengucapkan suara konsonan maupun vokal dari kata-kata dalam Bahasa Inggris. Hal ini disebabkan oleh perbedaan pengucapan suara fonetic atau sistem ejaan pada Bahasa Inggris dan Bahasa Indonesia; misalnya huruf ' $\mathrm{G}$ ' pada Bahasa Indonesia diucapkan sebagai /ge/ sedangkan dalam Bahasa Inggris diucapkan sebagai /jei/, serta misalnya huruf 'I' pada Bahasa Indonesia diucapkan sebagai /i/ namun dalam Bahasa Inggris diucapkan sebagai /ai/. Perbedaan pengucapan suara konsonan dan vokal ini mengakibatkan seringkali terjadi kekeliruan dalam pengucapannya misalnya ketika mahasiswa berbicara dalam Bahasa Inggris namun pengucapan suara konsonan dan vokalnya menggunakan pengucapan dalam Bahasa Indonesia.

3) Kesulitan dalam menentukan stressed dan unstressed syllables.

Pengucapan kata-kata dalam Bahasa Inggris yang sangat memperhatikan 
adanya stressed dan unstressed syllables juga menimbulkan kesulitan bagi mahasiswa dalam berbicara dengan menggunakan Bahasa Inggris. Hal ini menjadi sulit karena dalam Bahasa Indonesia cenderung tidak memperhatikan penekanan dalam pengucapan sebagian besar katakatanya kecuali jika ada fungsi tertentu terkait penekanan khusus pada arti kata.

4) Kesulitan dalam mengenali dan pengucapan weak sounds.

Weak sounds juga menjadi salah satu karakter dari Bahasa Inggris yang menjadi bagian dari kesulitan mahasiswa terkait pengucapannya. Weak sounds juga bukan merupakan karakter Bahasa Indonesia sehingga cukup sulit bagi mahasiswa untuk lebih menyadari dan memahami keberadaannya sehingga bisa membantu pengucapan Bahasa Inggris yang lebih natural.

5) Kesulitan dalam mengidentifikasi homographs (kata-kata dengan ejaan yang sama namun memiliki pengucapan yang berbeda) dan homophones (kata-kata yang memiliki ejaan yang berbeda namun dengan pengucapan yang sama).

Sistem ortografi Bahasa Inggris dikenal sebagai sistem ortografi yang tidak konsisten, oleh karena itu sangat sering ditemui adanya pengucapan kata-kata yang tidak konsisten. Hal ini menimbulkan adanya homographs dan homophones dalam Bahasa Inggris. Misalnya pada kata 'read' pada kedua kalimat berikut ini: 1) I can't read your writing, dan 2) She picked up the letter and read it. Kata 'read' pada dua kalimat tersebut seharusnya diucapkan dengan pengucapan yang berbeda, walaupun memiliki ejaan yang sama persis. Pada homophones, misalnya pada kata-kata berikut: aloud dan allowed, flu dan flew, flour dan flower, dan lain-lain.

6) Kesulitan dalam pengucapan suku kata yang tepat / kesulitan dalam mengidentifikasi jumlah suku kata yang harus diucapkan dalam sebuah kata.

Pengucapan suku kata dalam Bahasa Indonesia cenderung sangat mudah karena sesuai dengan sistem ejaannya, namun dalam Bahasa Inggris tidaklah demikian. Seringkali pengucapan suku kata dengan ejaannya tidak sejalan. Misalnya pada kata yang dari ejaannya terlihat seperti memiliki empat suku kata namun ternyata pada pengucapanya hanya terdiri dari tiga suku kata seperti pada kata 'secretary'.

7) Kesulitan dalam pengucapan akhiran dari sebuah kata secara tepat.

Akhiran -s dan akhiran - d pada katakata dalam Bahasa Inggris juga cenderung mengakibatkan kesulitan bagi para mahasiswa dalam pengucapannya. Seringkali akhiran tersebut yang seharusnya mendapatkan porsi suara yang signifikan dalam pengucapannya namun tidak terdengar ketika diucapkan oleh mahasiswa ketika mereka sedang berbicara.

Selain faktor-faktor terkait kesulitan-kesulitan yang dialami oleh mahasiswa dalam mempelajari pronunciation diatas, ada hal lain juga yang sangat perlu untuk diperhatikan oleh para Dosen. Hal tersebut adalah adanya faktor: 1) kelalaian akan produksi lisan mereka terutama dalam pengucapan atau pronunciation yang benar, 2) kemalasan untuk mengecek apakah mereka telah menggunakan pronunciation yang benar atau tidak serta mempelajari pronunciation kata-kata baru, dan 3) ketidaksadaran akan pentingnya pronunciation yang benar dalam 
berkomunikasi dengan menggunakan Bahasa Inggris.

\section{Strategi Pengajaran Pronunciation.}

Dari hasil analisa yang telah dilakukan, peneliti menyajikan beberapa hal terkait strategi pengajaran pronunciation. Strategi pengajaran ini diharapkan dapat digunakan oleh para dosen sehinga dapat membantu memperbaiki kemampuan pronunciation para mahasiswa. Adapun strategi pengajaran tersebut adalah sebagai berikut:

1. Beri prioritas pada pronunciation (but be realistic): Beri prioritas untuk membantu memperbaiki pronunciation mahasiswa setiap kali mereka mendapat masalah dengan hal ini. Dosen tidak harus mengajar pronunciation untuk memberikan masukan dan koreksi pada pronunciation mahasiswa. Prinsip yang perlu diterapkan dalam memperbaiki pronunciation mahasiswa adalah "little but often". Hal ini akan dengan sedikit demi sedikit membantu mahasiswa untuk memiliki pronunciation yang lebih baik. Namun perlu diingat juga bahwa yang sangat dibutuhkan oleh para mahasiswa adalah kejelasan dan kepercayaan diri ketika mereka berbicara, bukan kesempurnaan pada setiap detail. Koreksi pada pronunciation harus dilakukan tanpa terlalu dipaksakan. Lakukan lagi pada saat yang lain, akan lebih baik daripada memaksakan pada saat yang kurang tepat. Cara yang menyenangkan dalam melakukan koreksi juga akan membantu mahasiswa agar tidak merasa malu atau tertekan.

2. Drill: Salah satu cara termudah dalam melatih pronunciation adalah melalui pengulangan (repetition) baik secara bersama-sama atau secara individu. Repetition dapat membantu mahasiswa membangun kepercayaan dirinya dan sangat efektif untuk tingkatan low-level asalkan tidak dilakukan secara berlebihan.

3. Contoh yang benar dan jelas: Pastikan bahwa mahasiswa dapat mendengar contoh pronunciation yang benar dan jelas. Jika contoh yang diberikan tidak benar atau tidak dapat terdengar dengan jelas maka mahasiswa tidak akan dapat memproduksi pronunciation yang benar sebagai output. Pada tingkatan low-level hal ini dapat dilakukan dengan cara mengulang hingga tiga kali contoh yang diberikan sebelum meminta mahasiswa untuk menirukan. Terkadang beberap suku kata atau suara yang perlu mendapatkan perhatian harus diulang pengucapannya secara individual sehingga dapat terdeteksi dengan jelas. Selain itu menonjolkan penekanan suara dan juga intonasi diperlukan agar mudah diidentifikasi dan ditiru. Selain itu, bandingkan ucapan yang benar dengan pengucapan yang salah yang dihasilkan oleh mahasiswa. Pembandingan ini dapat dilakukan antara pengucapan yang benar pada kata yang dimaksud dengan pengucapan yang mirip dalam Bahasa Inggris atau dengan pengucapan dalam Bahasa Indonesia.

4. Beri perhatian khusus pada kata-kata yang memiliki cara penulisan yang tidak konsisten: Salah satu kesulitan terbesar yang dihadapi oleh para pembelajar Bahasa Inggris adalah ketidakkonsistenan antara penulisan dan pengucapan dalam Bahasa Inggris. Drill dan beri perhatian khusus pada problem words secara konsisten. Penggunaan phonemic alphabet dalam memberikan petunjuk pronunciation perlu juga dilakukan 
agar mahasiswa dapat melakukan cek pronunciation secara mandiri.

5. Fokus pada suara yang paling berpengaruh pada pemahaman mahasiswa: Suara konsonan khususnya yang berada pada awal dan akhir dari kata terkadang lebih penting daripada suara vokal. Bantulah mahasiswa untuk mereproduksi pengucapan yang benar. Minimal pair sangat berguna untuk dijadikan contoh perbedaan pengucapan bagi mahasiswa, misalnya pada kata tree dan three. Beri contoh pengucapan dari minimal pair tersebut beberapa kali, lalu minta mahasiswa untuk mengenali kata yang diucapkan. Selanjutnya minta mereka untuk mereproduksi kata yang sama.

6. Beri perhatian khusus pada schwa (ə): Schwa (ə) merupakan suara vokal yang paling umum dalam Bahasa Inggris yang muncul dengan persentase yang sangat tinggi pada kata-kata yang memiliki multi sukukata. Penggunaan schwa (ə) yang benar akan membantu mahasiswa menjadi terdengar lebih fluent dan juga lebih mudah dimengerti. Pastikan untuk fokus pada pengucapan schwa yang benar setiap kali menemukannya, namun jangan sampai salah memberikan tekanan pada schwa tersebut karena sukukata yang mengandung schwa biasanya tidak diucapkan dengan tekanan. Ucapkan suara schwa secara konsisten ketika kita menuliskan kata yang mengandung schwa tersebut juga akan sangat membantu mahasiswa untuk lebih peka terhadap keberadaan schwa.

7. Fokus secara konsisten pada word stress: Selalu fokuskan mahasiwa pada penekanan kata atau word stress setiap kali kata baru atau kata yang kemungkinan akan menimbulkan kesalahan pengucapan. Teknik drill berikut dapat digunakan untuk membantu mahasiswa:

a. Beri penekanan suara yang lebih pada bagian dari word stress.

b. Tepukan tangan serta suara klik dari jari-jari tangan dapat digunakan untuk memfokuskan mahasiswa pada bagian yang memerlukan tekanan suara.

c. Gumamkan pola tekanan suara terlebih dahulu sebelum menerapkannya pada kata yang akan digunakan juga sangat membantu (missal: mm-MM$\mathrm{mm})$.

d. Isolasi sukukata yang memerlukan tekanan, lalu baru tambahkan suku kata yang lain.

e. Beri tanda pada sukukata yang memerlukan penekanan ketika menuliskannya di papan tulis dan biasakan mahasiswa untuk melakukan hal yang serupa ketika mereka menuliskan vocabulary baru di buku mereka.

8. Fokus secara konsisten pada sentence stress: Selalu fokuskan mahasiwa pada penekanan kalimat atau sentence stress setiap kali mereka berbicara. Teknik drill seperti pada poin tujuh diatas dapat digunakan untuk membantu mahasiswa.

9. Selalu ingatkan mahasiswa untuk lebih berhati-hati dalam mengucapkan kata-kata dalam Bahasa Inggris dengan memperhatikan pengucapan atau pronunciation yang benar.

10. Selalu ingatkan mahasiswa untuk mengecek pengucapan yang benar dari kata-kata dalam Bahasa Inggris yang mereka gunakan di kamus ataupun sumber lainnya. Pastikan juga bahwa mereka mempelajari pronunciation yang benar dari katakata yang baru mereka pelajari. 
11. Selalu tekankan kepada mahasiswa tentang pentingnya pengucapan atau pronunciation yang benar dalam berkomunikasi dengan menggunakan Bahasa Inggris. Beri contoh-contoh situasi yang bisa menimbulkan kesalahpahaman jika mereka menggunakan pronunciation yang salah dalam ucapan-ucapan mereka menggunakan Bahasa Inggris.

Selain strategi pengajaran tersebut diatas, hal yang juga sangat penting untuk meningkatkan kemampuan pronunciation mahasiswa yaitu dengan mengingatkan mereka bahwa ada strategi-strategi belajar pronunciation yang juga sebaiknya mereka terapkan. Strategistrategi tersebut yaitu:

- Mempelajari phonetic alphabet dalam Bahasa Inggris

- Menggunakan kamus digital baik online maupun offline yang dilengkapi dengan audio

- Mendengarkan berbagai sumber yang dapat dijadikan acuan sebagai contoh pengucapan dalam Bahasa Inggris yang benar (terutama dari sumber native speaker)

- Praktik membaca keras akan sangat membantu untuk mengidentifikasi pengucapan yang salah atau tidak tepat.

- Mempelajari pengucapan seluruh kata yang digunakan. Pastikan untuk selalu mengecek pengucapan yang benar dari kata-kata baru yang dipelajari.

- Rubah kebiasaan-kebiasaan (misalnya aksen yang terlalu kental) yang berasal dari Bahasa ibu.

\section{Simpulan}

Berdasarkan identifikasi dan analisa data yang dilakukan oleh peneliti, dari 33 mahasiswa yang menjadi subjek penelitian ini, ditemukan bahwa sebanyak 2 orang mahasiswa kemampuannya masih berada pada level Non-English, 18 orang mahasiswa berada pada level Intrusive, 11 orang mahasiswa berada pada level intermediate, dan 2 orang berada pada level good.

Dari identifikasi tersebut, kesulitan yang dihadapi mahasiswa dalam pronunciation Bahasa Inggris sebagai berikut: 1) Kesulitan dalam menghilangkan pengaruh Bahasa ibu yang masih kuat, 2) Kesulitan dalam pengucapan suara konsonan dan suara vokal yang tepat (Kesulitan dalam membiasakan diri dengan pengucapan suara fonetic dalam Bahasa Inggris), 3) Kesulitan dalam menentukan stressed dan unstressed syllables, 4) Kesulitan dalam mengenali dan pengucapan weak sounds, 5) Kesulitan dalam mengidentifikasi homographs (kata-kata dengan ejaan yang sama namun memiliki pengucapan yang berbeda) dan homophones (kata-kata yang memiliki ejaan yang berbeda namun dengan pengucapan yang sama), 6) Kesulitan dalam pengucapan suku kata yang tepat / kesulitan dalam mengidentifikasi jumlah suku kata yang harus diucapkan dalam sebuah kata, dan 7) Kesulitan dalam pengucapan akhiran dari sebuah kata secara tepat.

Adapun strategi pengajaran yang disarankan oleh peneliti adalah dengan: 1) memberikan prioritas pada pronunciation (but be realistic), 2) melakukan drill, 3) selalu menyediakan banyak contoh yang benar dan jelas, 4) selalu memberikan perhatian khusus pada kata-kata yang memiliki cara penulisan yang tidak konsisten, 5) fokus pada suara yang paling berpengaruh pada pemahaman mahasiswa, 6) beri perhatian khusus pada schwa (ə), 7) fokus secara konsisten pada word stress, serta 8) fokus secara konsisten pada sentence stress.

Selain itu, peneliti juga menyimpulkan bahwa terdapat faktorfaktor yang berasal dari mahasiswa sendiri yang menyebabkan mereka 
kesulitan dalam meningkatkan kemampuan pronunciation nya. Faktorfaktor tersebut yaitu: 1) kelalaian akan produksi lisan mereka terutama dalam pengucapan atau pronunciation yang benar, 2) kemalasan untuk mengecek apakah mereka telah menggunakan pronunciation yang benar atau tidak serta mempelajari pronunciation kata-kata baru, dan 3) ketidaksadaran akan pentingnya pronunciation yang benar dalam berkomunikasi dengan menggunakan Bahasa Inggris.

Pronunciation harus selalu menjadi bagian yang penting untuk diperhatikan oleh para Dosen dalam pembelajaran Bahasa Inggris. Hal ini menjadi semakin krusial karena mahasiswa pada Prodi Pendidikan Bahasa Inggris kelak akan menjadi guru-guru Bahasa Inggris yang menjadi model bagi para muridnya kelak. Terkait dengan hal ini peneliti memberikan saran kepada para Dosen di Prodi Pendidikan Bahasa Inggris untuk terus memperhatikan kemampuan pronunciation para mahasiswanya, membantu mereka untuk mengatasi kesulitan-kesulitan yang mereka hadapi, dan selalu memberikan masukan serta feedback yang terkait dengan kemampuan pronunciation dari mahasiswa sehingga mereka dapat terus meningkatkan kemampuan mereka terutama dalam hal pronunciation.

\section{Pustaka Rujukan}

Berg, B. L. (2001). Qualitative Research Methods for Social Science. Needham Heights, MA: Pearson Education Company.

Brown, H. D. (2000). Principle of Language Learning and Teaching. San Francisco, NY: Longman.

Fraser, H. (1999). ESL Pronunciation Teaching: Could it be More Effective?. Paper presented at the AALA Conference. Perth.
Gilbert, J. B. (2008). Teaching Pronunciation. Cambridge, UK: Cambridge University Press.

Scrivener, J. (2005). Learning Teaching: A Guide Book for English Language Teachers. Oxford, UK: Macmillan Education.

Stern, H. H. (1991). Fundamental Concepts of Language Teaching. Oxford, UK: Oxford University Press. 